\title{
CUSTOMER SATISFACTION LEVEL BETWEEN SHOPPING AT ONLINE SHOP AND OFFLINE SHOP AT THE CAMPUS OF THE DARUSSALAM INSTITUTE OF ISLAM (IAID) CIAMIS
}

\author{
Tazkiyah Ainul Qolbi \\ Institut Agama Islam Darussalam (IAID) Ciamis-Jawa Barat \\ Email: isti.tresnaaristantia@gmail.com \\ Rini Febriani \\ Institut Agama Islam Darussalam (IAID) Ciamis-Jawa Barat
}

Agus Muslim

Institut Agama Islam Darussalam (IAID) Ciamis-Jawa Barat

\begin{abstract}
This research was conducted to determine consumer satisfaction in shopping at online shops and offline shops. This study uses a quantitative approach because the data obtained is realized in the form of numbers and analyzed based on statistics. The results showed a difference in shopping satisfaction between the online shop and the offline shop. It is evidenced by obtaining significant results so that it can be concluded that the null hypothesis is rejected and the working hypothesis is accepted. The average student who does not like to shop at online shops is because they are not satisfied when shopping at online shops and get products that do not match what is stated in the description of the goods in the selected online shop. Usually, this happens in individual online shops on social media (not on trusted sites) and product brands that are not yet well known. However, the study results found several respondents who had shopped at a credible online shop and felt satisfied because it was as expected. As for the offline shop, the average student feels more satisfied because consumers can see firsthand the quality of the product and try the product to be purchased.
\end{abstract}

\begin{abstract}
Abstrak
Penelitian ini dilakukan untuk mengetahui tingkat kepuasan konsumen dalam berbelanja di online shop dan offline shop. Serta, untuk mengetahui adakah perbedaan kepuasan dalam berbelanja diantara keduanya di kalangan mahasiswa Fakultas Syari'ah Institut Agama Islam Darussalam Ciamis. Penelitian ini menggunakan pendekatan kuantitatif, karena data yang diperoleh diwujudkan dalam bentuk angka dan dianalisis berdasarkan statistik. Hasil penelitian menunjukkan adanya perbedaan kepuasan berbelanja antara online shop dengan offline shop. Hal ini dibuktikan dengan diperolehnya hasil yang signifikan sehingga dapat disimpulkan Hipotesis Nol ditolak dan Hipotesis Kerja diterima. Rata-rata mahasiswa yang tidak gemar berbelanja pada online shop dikarenakan alasan kurang puas saat berbelanja pada online shop dan mendapatkan produk yang tidak sesuai dengan yang tertera pada deskripsi barang di online shop yang dipilih. Biasanya, hal ini terjadi pada online shop yang bersifat individual di media sosial (bukan dalam situs terpercaya) dan brand produk yang belum terkenal. Namun, hasil penelitian menemukan beberapa responden yang pernah berbelanja pada online shop yang kredibel dan mera sakan puas karena sesuai dengan yang diharapkan. Adapun pada offline shop, rata-rata mahasiswa merasa lebih puas karena pada offline shop, konsumen dapat melihat langsung kualitas produk dan mencoba produk yang akan dibeli tersebut.
\end{abstract}


Keywords: Consumer Satisfaction, Online Shop, Offline Shop

\section{Introduction}

Buying and selling or doing business in Islam is a noble job. Business in Islam can be interpreted as a series of business activities in various forms that are not limited by the amount (quantity) of ownership of property (goods/services), including profits, but are limited in how to acquire and utilize their assets (there are halal and haram rules). However, online purchases have several drawbacks related to security and direct contact with products, whereas Abdurrahman (2015: 90) believes that shopping online can make it easier for consumers to get the products they want. The products offered in the online shop are sometimes more attractive than the offline shop. The use of the internet as a marketing medium and sales channel has been proven to have advantages, among others, for certain products that are more suitable to be offered via the internet at lower prices. Creating a website on the internet is cheaper than opening retail outlets in various places. The internet is the most appropriate promotional media for companies and products with relatively cheaper prices, and delivery services will follow purchases via the internet to the place of order.

In doing business, customer satisfaction is also critical because it affects the success of a business. If consumers are not satisfied with the quality of products or services in a business transaction, it will also affect the business's level of success. Not a few are disappointed with the quality of the goods purchased at the online shop. They are more comfortable choosing offline shopping because the quality of the goods ordered differs from what was received when the product arrived at home. Contribution to customer satisfaction must be a priority for companies to improve their service levels. It applies to all types of online and offline businesses. As in Islam, it is explained that consumer satisfaction, namely to meet needs, tends to choose goods and services that provide maximum maslahah, which are closely related to needs, desires, benefits, blessings, beliefs, and halal.

Based on the literature review that was found, the authors obtained one of the published studies regarding the comparative analysis of consumer satisfaction between shopping at an online shop and an offline shop. The research title is "User Satisfaction Analysis Comparison Between Conventional Sales With Online Sales."

The relevant research conducted by Megawaty (2015:3) examines the analysis of user satisfaction levels comparison between conventional sales and online sales, which results in consumers' high level of satisfaction on shopping made directly compared to shopping online. Even though direct selling is now endemic with the times, users who are customers are very good at choosing the type of online sales that is safe and reliable.

By looking at the breadth of the development of the business world today, especially online business, which is now increasingly booming, the author decided to raise the theme of comparing the level of consumer satisfaction in shopping between online shops and offline shops among students of the Darussalam Ciamis Islamic Institute. 


\section{Theoretical Review}

\section{The Concept of Consumer Satisfaction}

Currently, the concept of service quality to consumers has become the main thing that supports a company's success. When customers feel excellent service from manufacturers, then they not only get satisfaction but also get pleasure. If a business is not supported by good service, then the business will not succeed.

Consumer satisfaction is a person's feelings of pleasure or disappointment arising from comparing the product's perceived performance (or result) against their expectations. If performance fails to meet expectations, the customer will be dissatisfied. If performance matches expectations, customers will be satisfied. If performance exceeds expectations, the customer will be very satisfied or happy. Customer ratings of product performance depend on many factors, especially the loyalty relationship a customer has with a brand. Consumers often form more favorable perceptions of a product with a brand they already perceive as positive. So, how do buyers start their expectations? Expectations come from past buying experiences, advice from friends and associates, and information and promises from marketers and competitors. If marketers raise expectations too high, buyers will be disappointed. However, if the company sets expectations too low, it will not attract enough buyers (although it will satisfy those who do). Some of today's most successful companies raise expectations and deliver performance that meets expectations (Kotler and Keller, 2009:138-139).

In many companies globally, the level of service that makes consumers feel satisfied is service that is in favor of consumers. If services are provided to consumers, consumers will think that their interests are being cared for. Good service can raise product sales because consumers are satisfied with the level of service provided (Kirom, 2015:13).

\section{Online Shop Concept}

The latest form of trade that makes it easier for users is now known as ecommerce, or e-business. Shopping through business e-commerce is now increasingly known to all levels of society worldwide. People usually call it an online shop, and the online shop itself is part of E-Commerce. For the consumer, using E-Commerce can make making time short and easy.

A contract is an essential element in a business. Buying and selling have not been said to be valid before the consent and qabul are made because the ijab and qabul show willingness (pleasure). The presence of willingness cannot be seen because willingness is related to the heart; the will can be known through the signs of birth, a clear sign that shows the desire is consent and qabul. As explained in the hadith of the Prophet:

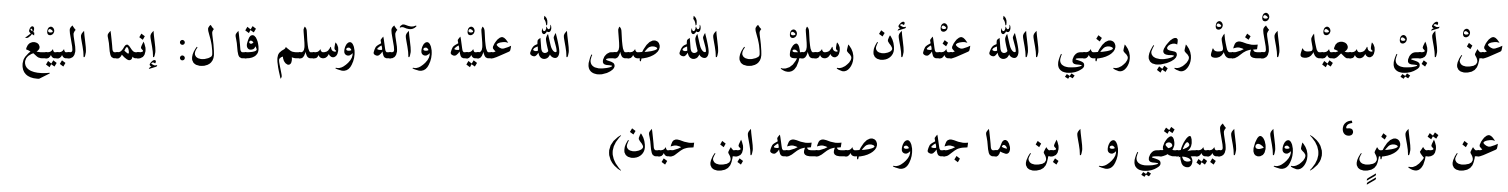


From Abu Sa'id Al-Khudri that the Messenger of Allah said, "Indeed, buying and selling must be done consensually." (Narrated by Al-Baihaqi and Ibn Majah, and assessed as authentic by Ibn Hibban).

According to Hediana and Aly (2002:46-47), in general, business in Islam explains the existence of physical transactions by presenting the object during the transaction, or without showing the object ordered, but with the condition that the nature of the object must be stated concretely, either handed over directly or submitted later until a certain time limit, as in the transaction as-salam. As-salam transaction is a form of transaction with a cash payment system or hastily, but goods delivery is suspended. According to the scholars, as-salam can be defined as a transaction or sale, and purchase contract in which the goods being traded do not exist when the transaction is made, and the buyer makes an upfront payment while the delivery of the goods is made at a later date. The implementation of as-salam in buying and selling, namely goods characterized (with certain criteria), depends on (the seller) with cash payments at the contract agreement.

According to Abdurrahman (2015: 104-106), salam is "a form of buying and selling by handing over the current medium of exchange for compensation which is described as being independents to a certain time. Salam is done with whatever is used to contract the sale and purchase and with the greeting or salaf lafadz. The online shopping business is currently growing rapidly among the broader community worldwide. Various stories and testimonies from online shop actors are increasingly being found in cyberspace and the real world.

\section{Offline Shop Concept}

According to Hermawan (1999:45), offline shop is "a transactional process of buying and selling between consumers and sellers directly and there is interaction with product sellers in which there is a series of brands (products sold), process (direct exchange) and service at the same place and the same as consumers.

Basically, the offline business will make the level of consumer confidence higher. This is because offline businesses have a physical store that consumers can visit directly. Consumers will see and feel the product before finally deciding to buy it. Usually, consumers will only go to an offline store if they like something displayed on a storefront or get information to come to a particular store because of the right collection. In addition, in offline shops, consumers can interact directly with sellers and bargain prices. The transaction process, bargaining and merchant strategies in attracting consumers are also evident.

Difference between Manual Trading Process (Offline Shop) and E-Commerce (Online Shop)

According to Lohse and Spiller (1999) in Binus (2002: 9-10) they are of the view that along with the development of the internet world, both in terms of infrastructure and the services offered, traditional buying and selling transactions that were previously done physically can now be done virtual via internet. Internet Network. This change in buying and selling methods also has an impact on the behavior and shopping orientation of these consumers. In the following table, are the differences between traditional and online shopping methods. 


\begin{tabular}{|c|c|c|}
\hline No & Traditional Shopping (Offline) & Online Shoping \\
\hline 1 & Hosted by Shopkeeper & $\begin{array}{l}\text { Product description, information page, gift } \\
\text { delivery service, search function, telephone } \\
\text { or e-mail service. }\end{array}$ \\
\hline 2 & Promotion & $\begin{array}{l}\text { Special offers, online games, links to other } \\
\text { websites. }\end{array}$ \\
\hline 3 & Storefront & Website home page. \\
\hline 4 & Store Layout & $\begin{array}{l}\text { Use of colors \& images, support functions, } \\
\text { indexes. }\end{array}$ \\
\hline 5 & Number of Floors in Store & Hierarchical structure of the store. \\
\hline 6 & Shop Shelf & Products are arranged hierarchically. \\
\hline 7 & Cashier & shopping cart \\
\hline 8 & Number of Store Branches & $\begin{array}{l}\text { Number of links referring to one of the } \\
\text { online stores. }\end{array}$ \\
\hline 9 & Item Physical Form & $\begin{array}{l}\text { Physical form of goods Limited to images } \\
\text { and videos, sometimes sound and certain } \\
\text { applications. }\end{array}$ \\
\hline 10 & $\begin{array}{l}\text { Accumulated number of logged in } \\
\text { customers }\end{array}$ & $\begin{array}{l}\text { The accumulated number of unique visits to } \\
\text { the online store. }\end{array}$ \\
\hline 11 & Sales per period & Sales per period. \\
\hline
\end{tabular}

\section{Methods}

This study uses a quantitative approach, because the data obtained is realized in the form of numbers and analyzed based on statistics. To complete this research, the researcher used the comparative statistical method. This research is a research with ordinal data. According to Sugiyono (2016:7) ordinal data is quantitative data that is continuous with each other in one line. This data is obtained from measuring results, such as measuring health status, weight, ability, motivation, IQ, and others. Ordinal data can be said as continuum data.

The data analysis used in this study are as: First, the validity test. This data validity test aims to determine the validity of the data we obtain. The validity shows the extent to which a measuring instrument measures what it wants to measure. A valid instrument means that the measuring instrument used to obtain data (measure) is valid. Valid means that the instrument can be used to measure what is to be measured, so that validity means the extent to which the accuracy and accuracy of a measuring instrument in carrying out its measuring function and its relation to the measurement objectives. The second, the reliability test. This reliability test aims to find out the valid data continuously, or there are irregularities (some are invalid) so that it cannot be said that the data is reliable. This test must exist, to ensure that the data is suitable for use. 
Third, normality test. To fulfill the prerequisites for data analysis, a normality test was carried out. Normality test is intended to determine whether the relevant data is normally distributed or not. The normality test uses Kolmogrov-Smirnov to see if the data is normally distributed or not. If the significant value is more than 0.05 then the data is normally distributed, but if the significant value is less than 0.05 then the data is not normally distributed. The Independent T-Test is a comparative test or different test used to determine whether two unrelated samples have different mean values. If the significant value $>$ alpha $(\alpha) 0.05$, it is said that there is a taste variant from the two groups, and vice versa.

\section{Results and Discussion}

This research was conducted at the Syari'ah Faculty, Darussalam Islamic Institute, Ciamis. Respondents who were taken as research objects were students of the Syari'ah Faculty at the Darussalam Ciamis Islamic Institute with a recorded number of 65 students who were used as samples. Researchers distributed questionnaires to 65 respondents, namely 9 students from the Akhwal As-Syakhsiyah study program and 56 students from the Sharia Economics study program.

The age of the respondents in this study was dominated by ages in the 18-29 range. The results of the study of the age of respondents who shopped at online shops were between the age category of 18-23 years and the age category of 24-29 years, where the age of $18-23$ years was $92.3 \%$ while the age of $24-29$ years was $7.7 \%$. So it can be seen that the difference between the two is $84.6 \%$.

In this study, respondents with male sex amounted to $27.7 \%$ while respondents with female sex amounted to $72.3 \%$ so it can be concluded that respondents who participated in the study were female. So it can be seen that the difference between the two is $44 \%$.

Classification of respondents based on the type of goods purchased at the online shop. The majority of the items purchased by respondents at the online shop are fashion at $83.1 \%$, electronics $9.2 \%$, others $4.6 \%$ and the remaining $1.5 \%$. Classification of respondents based on the amount of shopping at the online shop. The majority of respondents' purchases at online shops were $83.1 \%$ for 1-6 purchases, $10.8 \%$ for 7-12 purchases. $3.1 \%$ for $19-24 \%$, and the remaining $1.5 \%$.

Classification of respondents based on electronic media used in shopping at the online shop. The majority of respondents shopped at online shops using smartphone electronic media by $93.8 \%$, using a PC/Laptop by $4.6 \%$, and using a tablet by $1.5 \%$. Classification of respondents based on social media used in shopping at the online shop. The majority of respondents use the Instagram application in shopping at online shops by $36.9 \%$, with WhatsApp by $27.7 \%$, with Facebook by $18.5 \%$, and the rest using other applications. Classification of respondents based on where to shop in the offline shop. The majority of respondents more often visit traditional markets by $64.6 \%$, and visit modern markets by $35.4 \%$. So it can be seen that the difference between the two is $29 \%$. 
The results of the Kolmogorov Smirnov test for the Independent Sample T-Test in this study are that the results of the normality test based on the table above show that the sig. has a value of 0.283 . It means $0.283>0.05$ or sig. $>$ alpha $(\alpha)$ so it can be stated that the standardized residual value is normally distributed. So to further test the hypothesis. In connection with testing the hypothesis that there are differences in shopping satisfaction between online shops and offline shops, the results show significant differences. This is evidenced by the obtaining of a significant value of 0.000 $<0.05$, so according to the basis of decision making in the independent sample t-test test, it can be concluded that Ho is rejected and Ha is accepted, which means that there are differences in consumer satisfaction in shopping at online shops with offline shops among consumers. students of the Syari'ah Faculty, Darussalam Islamic Institute, Ciamis. From the table, it can be seen that consumer satisfaction shopping for students of the Syari'ah Faculty of the Islamic Institute of Darussalam Ciamis in the online shop is 28.58, while the average consumer satisfaction shopping for students of the Syari'ah Faculty, Darussalam Ciamis Islamic Institute in the offline shop is 25.62. On average, it can be seen that online shop satisfaction is lower than offline shop.

\section{Conclusion}

Based on the discussion that has been described regarding the Comparative Analysis of Online Shop Consumer Satisfaction Levels in the Ba'i Salam Agreement with Offline Shops Among Syari'ah Faculty Students, Darussalam Ciamis Islamic Institute, the following conclusions can be drawn: (1) Based on the results of testing the analysis data on consumer satisfaction shopping online shop using SPSS (Statistical Product and Service Solution), the mean score of 28.58 is classified as less satisfied, because it is in the range of scores of 25.5-29. On average, students do not like to shop at online shops due to reasons they are not satisfied when shopping at online shops and get products that do not match what is shown in the picture in the selected online shop. Usually, this happens in individual online shops on social media (not on trusted sites) and product brands that are not yet well known. However, the results of the study found several respondents who had shopped at a credible online shop and were satisfied because it was as expected. (2) Based on the results of the analysis of customer satisfaction analysis data shopping offline shop using SPSS (Statistical Product and Service Solution), then the mean score of 25.62 is classified as satisfied, because it is in the range of scores of 25.3-28.3. From the research results, on average, students are more satisfied when shopping at an offline shop because consumers can see firsthand the quality of the product and try the product to be purchased. (3) In relation to testing the hypothesis which states that there are differences in shopping satisfaction between online shops and offline shops, the results show that there are significant differences. This is evidenced by the obtaining of a significant value of $0.000<0.05$, so according to the basis of decision making in the independent sample t-test test, it can be concluded that $\mathrm{Ho}$ is rejected and $\mathrm{Ha}$ is accepted, which means that there are differences in consumer satisfaction in shopping at online shops with offline shops among consumers students of the Faculty of Islamic Sharia Darussalam ciamis. 


\section{REFERENCES}

Bekti Setiawati. 2006. Skripsi Pengaruh Kualitas Produk dan Promosi Terhadap Keputusan Pembelian Kerupuk Rambak “DWIYONO” di Desa Penanggulan Kec. Pegandon Kab. Kendal. Semarang. Hal: $30-41$.

http://jurnal/Produk Definisi, Klasifikasi, Dimensi Kualitas dan Tingkatan Produk.htm http://jurnal-sdm.blogspot.co.id/2009/o7/produk-definisi-klasifikasidimensi $30 . \mathrm{html}$

Kasmadi \& Sunariah. (2013). Panduan Modern Penelitian Kuantitatif. Bandung: Alfabeta.

Kasmadi \& Sunariah. (2013). Panduan Modern Penelitian Kuantitatif. Bandung: Alfabeta.

Kotler \& Armstrong. 2001. Prinsip-Prinsip Pemasaran. Jakarta: Erlangga.

Sugiyono . (2014). Metode Penelitian Kombinasi (Mixed Methods). Bandung: Alfabeta.

Sujarweni. (2014). Metodologi penelitian. Yogyakarta: Pustaka Baru Press.

Swastha. 2001. Manajemen Pemasaran Modern. Yogyakarta: BPFE.

Winardi. 2005. Manajemen Perubahan (The Management of Change). Cetakan Ke-1, Jakarta: Prenada Media. 